\title{
ANALISIS PENGARUH JUMLAH PENDUDUK, TABUNGAN, DAN INVESTASI TERHADAP TINGKAT PENDAPATAN PER KAPITA INDONESIA
}

\author{
Oleh : \\ Rudi Masniadi \\ Fakultas Ekonomi Universitas Cordova Nusa Tenggara Barat \\ E-mail/No.HP: rudi_masni@yahoo.com/-
}

\begin{abstract}
This research intent to know factor picture that regard to increase income / PDB per capita at Indonesia. In theoretical study, factor that regard perkapita's income for example population, savings and investment, as one is described in Model growth Theory Solow Swan. analisis's tool that is utilized is with Analisis's approaching bifilar Regression via methodics Ordinary Least Square (OLS). Of theory study and research result can be concluded that up to period 19902008 available negative correlation among propertied per capita with islandic growth, or gets to be said by resident growth cause decrease to income per capita Indonesia resident. In the meantime, savingses level variable (GDS) and investment $(G D C F)$, even in little percentage give positiv's influence to income per capita resident.
\end{abstract}

Keywords: Income / PDB Per Capita

\begin{abstract}
Abstrak
Penelitian ini bertujuan untuk mengetahui gambaran faktor-faktor yang mempengaruhi tingkat pendapatan/PDB per kapita di Indonesia. Dalam kajian teoritis, faktor-faktor yang mempengaruhi pendapatan perkapita antara lain jumlah penduduk, tabungan dan investasi, seperti yang diuraikan dalam Teori Pertumbuhan Model Solow-Swan. Alat analisis yang digunakan adalah dengan pendekatan Analisis Regresi Berganda melalui metode Ordinary Least Square (OLS). Dari kajian teori dan hasil penelitian dapat disimpulkan bahwa selama periode 1990-2008 terdapat korelasi negatif antara pendapatan per kapita dengan pertumbuhan penduduk, atau dapat dikatakan pertumbuhan penduduk menyebabkan penurunan terhadap pendapatan per kapita penduduk Indonesia. Sementara itu, variabel tingkat tabungan (GDS) dan investasi $(G D C F)$, meskipun dalam persentase yang kecil memberikan pengaruh positiv terhadap pendapatan per kapita penduduk.
\end{abstract}

Kata kunci : Pendapatan/PDB Per kapita

\section{PENDAHULUAN}

Kinerja perekonomian suatu ekonomi di masyarakat. Perkembangan negara umumnya diukur oleh beberapa indikator ekonomi yang bisa indikator-indikator ini tidak saja dapat mencerminkan tingkat kegiatan berpengaruh pada tingkat stabilitas ekonomi, tetapi juga pada tingkat 
kesejahteraan masyarakat secara keseluruhan. Salah satu indikator ekonomi terpenting adalah pertumbuhan ekonomi, yang untuk pencapaiannya tidak saja dipengaruhi oleh tersedianya pembiayaan yang memadai, tetapi juga oleh masalah distribusi sumber daya yang ada.

Dilihat dari pertumbuhan ekonomi, secara keseluruhan perekonomian Indonesia menggambarkan kinerja yang cukup menggembirakan selama periode tahun 2000-2008, dengan pencapaian pertumbuhan ekonomi yang relatif membaik. Bahkan sejak tahun 2004, ekonomi Indonesia memperlihatkan pertumbuhan ekonomi yang cukup berarti yaitu sekitar 5,05\% persen, pada tahun 2005 pertumbuhan ekonomi Indonesia mencatat tingkatan yang lebih tinggi lagi yaitu sekita 5,69\%. Dua tahun berikutnya, pada tahun 2006 dan 2007, pertumbuhan ekonomi berturutturut mencapai 5,51\% dan 6,28\%. Kemudian pada tahun 2008 ekonomi Indonesia tumbuh sekitar 6,1 \%, meskipun berada dalam berbagai tekanan dari sisi eksternal seperti tingginya harga minyak bumi dan harga beberapa komoditi lainnya, serta melambatnya pertumbuhan ekonomi global (FE UI, 2009).

Data-data di atas merupakan catatan prestasi makroekonomi Indonesia yang cukup membanggakan. Namun demikian, permasalahan yang tidak boleh dilupakan adalah apakah laju pertumbuhan output yang membanggakan ini memiliki kemampuan untuk bergerak lebih cepat daripada tingkat pertumbuhan penduduk. Dalam hal ini, indikator pendapatan/PDB per kapita memberikan gambaran pendapatan dan standar hidup rata-rata anggota individu penduduk. PDB per kapita adalah saham anggota individu dari populasi terhadap PDB tahunan. Secara matematis dihitung dengan membagi PDB riil atau nominal dengan jumlah penduduk per tahun.

Pendapatan perkapita juga merupakan ukuran yang digunakan untuk menggambarkan standar hidup (standard of living). Negara yang memiliki pendapatan perkapita yang tinggi umumnya memiliki standar hidup (standard of living) yang juga tinggi. Perbedaan pendapatan mencerminkan perbedaan kualitas hidup, negara kaya (dicerminkan oleh pendapatan per kapita yang tinggi) memiliki kualitas 
hidup yang lebih baik (dicerminkan oleh, antara lain, angka harapan hidup, tingkat kesehatan, dan tingkat pendidikan) dibandingkan dengan negara miskin (Mankiw, 2006).

Berdasarkan uraian di atas, maka yang menjadi fokus kajian dalam penelitian ini adalah apa saja faktorfaktor yang mempengaruhi tingkat pendapatan perkapita dan sejauhmana faktor-faktor tersebut mempengaruhi pendapatan perkapita.

Sebagai bahasan awal, akan dibahas tentang kosep pendapatan perkapita dan selanjutnya akan dibahas faktor-faktor yang mempengaruhi pendapatan per kapita melalui pendekatan Model Pertumbuhan Solow-Swan.

PDB per kapita adalah saham anggota individu dari populasi terhadap PDB tahunan. Secara matematis dihitung dengan membagi PDB riil atau nominal dengan jumlah penduduk pertahun. Pendapatan perkapita sering digunakan sebagai tolak ukur kemakmuran dan tingkat pembangunan sebuah negara semakin besar pendapatan perkapitanya, semakin makmur negara tersebut. Peningkatan pendapatan/PDB per kapita menandakan pertumbuhan ekonomi nasional (Madsen, 2006)

Teori pertumbuhan neoklasik dikembangkan oleh Robert M. Solow (1970) dari Amerika Serikat dan T.W Swan (1956) dari Australia. Model Solow-Swan menggunakan unsur pertumbuhan penduduk, akumulasi modal/capital, kemajuan teknologi, dan besarnya output yang saling berinteraksi (Tarigan, 2005).

Menurut Mankiw dalam Oktavia (2005), faktor utama yang mempengaruhi perbedaan standard of living (ditunjukkan oleh perbedaan besar pendapatan per kapita) antara negara kaya dan negara miskin adalah tingkat produktivitas. Produktivitas mengacu pada jumlah barang dan jasa yang dapat dihasilkan oleh seorang pekerja dalam setiap jam. Dengan demikian, suatu negara dapat menikmati standard of living yang tinggi jika negara tersebut dapat memproduksi barang dan jasa dalam jumlah yang besar.

Model pertumbuhan Solow dirancang untuk menunjukkan bagaimana pertumbuhan persediaan modal, pertumbuhan angkatan kerja, dan kemajuan teknologi berinteraksi dalam perekonomian, serta bagaimana 
pengaruhnya terhadap output barang dan jasa suatu negara secara keseluruhan. Dalam model ini, pertumbuhan ekonomi jangka panjang ditentukan secara exogen, atau dengan kata lain ditentukan di luar model. Model ini memprediksi bahwa pada akhirnya akan terjadi konvergensi dalam perekonomian menuju kondisi pertumbuhan steady-state yang bergantung hanya pada perkembangan teknologi dan pertumbuhan tenaga kerja. Dalam hal ini, kondisi steadystate menunjukkan equilibrium perekonomian jangka panjang (Mankiw, 2006).

Asumsi utama yang digunakan dalam model Solow adalah bahwa modal mengalami diminishing returns. Jika persediaan tenaga kerja dianggap tetap, dampak akumulasi modal terhadap penambahan output akan selalu lebih sedikit dari penambahan sebelumnya, mencerminkan produk marjinal modal (marginal product of capital) yang kian menurun. Jika diasumsikan bahwa tidak ada perkembangan teknologi atau pertumbuhan tenaga kerja, maka diminishing return pada modal mengindikasikan bahwa pada satu titik, penambahan jumlah modal (melalui tabungan dan investasi) hanya cukup untuk menutupi jumlah modal yang susut karena depresiasi. Pada titik ini perekonomian akan berhenti tumbuh, karena diasumsikan bahwa tidak ada perkembangan teknologi atau pertumbuhan tenaga kerja (Mankiw, 2006).

Mankiw dalam Oktavia (2005) juga menyebutkan bahwa jika diasumsikan terjadi pertumbuhan tenaga kerja (akibat pertumbuhan penduduk), pada jangka pendek, pertumbuhan output akan melambat karena adanya diminishing return dan perekonomian akan mengalami konvergensi ke arah tingkat pertumbuhan steady-state yang konstan (yaitu tidak ada pertumbuhan ekonomi per kapita). Jadi, model Solow memprediksi bahwa pertumbuhan penduduk akan memengaruhi standard of living suatu negara yang dicerminkan dalam PDB per kapita. Negara-negara dengan pertumbuhan penduduk yang tinggi akan memiliki tingkat GDP per kapita yang rendah,dan sebaliknya.

Model Solow diawali dari fungsi produksi $\mathrm{Y} / \mathrm{L}=\mathrm{F}(\mathrm{K} / \mathrm{L})$ dan dituliskan sebagai $y=f(k)$, dimana $y=Y / L$ dan $k$ $=\mathrm{K} / \mathrm{L}$. Fungsi produksi ini digambarkan dengan kurva oranye pada gambar (Grafik 1). Persamaan fungsi produksi 
ini menunjukkan bahwa jumlah output per pekerja (Y/L) adalah fungsi dari jumlah modal per pekerja (K/L). Fungsi produksi mengasumsikan diminishing returns terhadap modal yang dicerminkan dari kemiringan dari fungsi produksi tersebut. Kemiringan fungsi produksi menggambarkan produk marjinal modal (marginal product of capital) yang menggambarkan banyaknya output tambahan yang dihasilkan seorang pekerja ketika mendapatkan satu unit modal tambahan (Mankiw, 2006). Oktavia (2005) menyebutkan bawa model Solow dapat dituliskan secara matematis sebagai berikut (ibid: 204) :

$\Delta k=s f(k)-(n+\partial+g) k$

dengan:

$\mathrm{y}=\mathrm{f}(\mathrm{k})=\mathrm{F}(\mathrm{K} / \mathrm{L})$

$\mathrm{n} \quad=$ tingkat pertumbuhan penduduk

$\delta=$ depresiasi

$\mathrm{k} \quad=$ modal per pekerja $=\mathrm{K} / \mathrm{L}$

$\mathrm{y}=$ output per pekerja $=\mathrm{Y} / \mathrm{L}$

$\mathrm{s}$ = tingkat tabungan

$\mathrm{g}=$ tingkat perkembangan teknologi yang mengoptimalkan tenaga kerja.

Pada model Solow tanpa perkembangan teknologi, perubahan modal per pekerja ditentukan oleh tiga variabel berikut, Investasi (tabungan) per pekerja.

Pertumbuhan penduduk: pertumbuhan penduduk akan menurunkan tingkat modal per pekerja, Depresiasi: persediaan modal akan menurun karena penggunaan modal. Dalam kondisi steady-state, $\Delta \mathrm{k}$ harus sama dengan nol, sehingga: $s f\left(k^{*}\right)=(n$ $+\partial) k *$, dengan $\mathrm{k}^{*}$ adalah $\mathrm{k}$ pada kondisi steady-state dan $\mathrm{y}^{*}=\mathrm{f}\left(\mathrm{k}^{*}\right)$, Konsumsi pada kondisi steady-state menjadi $c^{*}=f\left(k^{*}\right)-(n+\partial) k *$ Secara grafis, model pertumbuhan Solow (tanpa perkembangan teknologi) dapat digambarkan seperti pada Gambar 1.

Jika sy $>(n+d) k$, atau jika tingkat tabungan lebih besar daripada tingkat pertumbuhan penduduk ditambah tingkat depresiasi (jika garis hijau berada di atas garis hitam pada gambar), maka modal per pekerja (k) akan naik. Kondisi ini dikenal sebagai capital deepening. Sementara capital widening merujuk pada kondisi saat modal meningkat pada tingkatan yang hanya cukup untuk mengimbangi pertumbuhan penduduk dan depresiasi. Kurva-kurva pada gambar di atas berpotongan di titik $\mathrm{A}$, yaitu titik steady-state. Padakondisi steady-state, output per pekerja adalah konstan. 
Namun demikian, output total tumbuh pertumbuhan penduduk, yaitu $n$. dengan kecepatan sama dengan

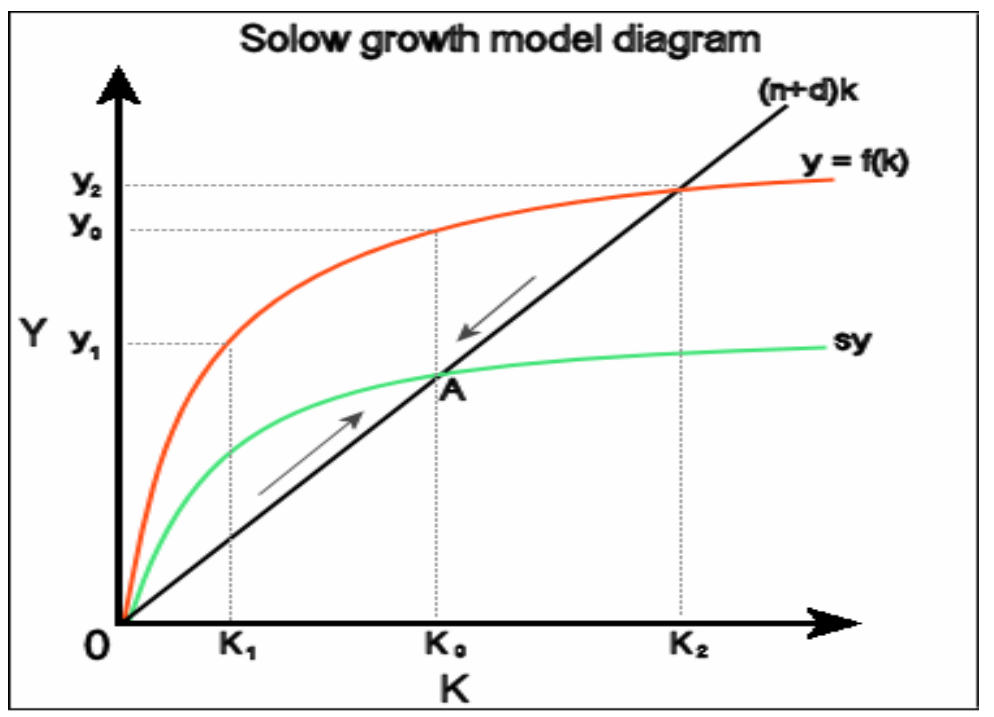

Gambar 1. Model Pertumbuhan Solow (tanpa perkembangan teknologi)

Sisi sebelah kiri titik A, misalnya titik k1, menunjukkan tabungan per pekerja yanglebih besar dibandingkan dengan jumlah yang dibutuhkan untuk mempertahankan tingkat modal yang mapan, sehingga mendorong peningkatan modal per pekerja. Ini menunjukkan capital deepening dari y1 ke y0, mendorong peningkatan output per pekerja. Di sebelah kanan titik A, dimana sy $<(\mathrm{n}+\mathrm{d}) \mathrm{k}$, misalnya pada titik k2, modal per pekerja menurun karena investasi tidak cukup mengatasi pertumbuhan penduduk dan depresiasi. Oleh karenanya, output per pekerja turun dari y2 ke y0.

Kurva biru menggambarkan fungsi tabungan kedua s1y (atau s1f(k)) yang menggambarkan naiknya tingkat tabungan. Tabungan per pekerja pada kondisi ini lebih besar dari pertumbuhan penduduk ditambah depresiasi, sehingga akumulasi modal meningkat yang menyebabkan pergeseran kondisi steady-state dari titik A ke B. Seperti dapat dilihat pada gambar, output per pekerja ikut bergeser dari y0 ke y1. Pertumbuhan tabungan pada awalnya menyebabkan perekonomian berkembang dengan cepat, namun akhirnya akan kembali ke kondisi steady-state dengan pertumbuhan sama dengan $n$ (pertumbuhan penduduk). Pada titik ini, jumlah modal dan produktivitas per pekerja lebih tinggi, namun pertumbuhan ekonomi berada 
pada tingkat yang sama dengan tabungan.

pertumbuhan sebelum ada peningkatan

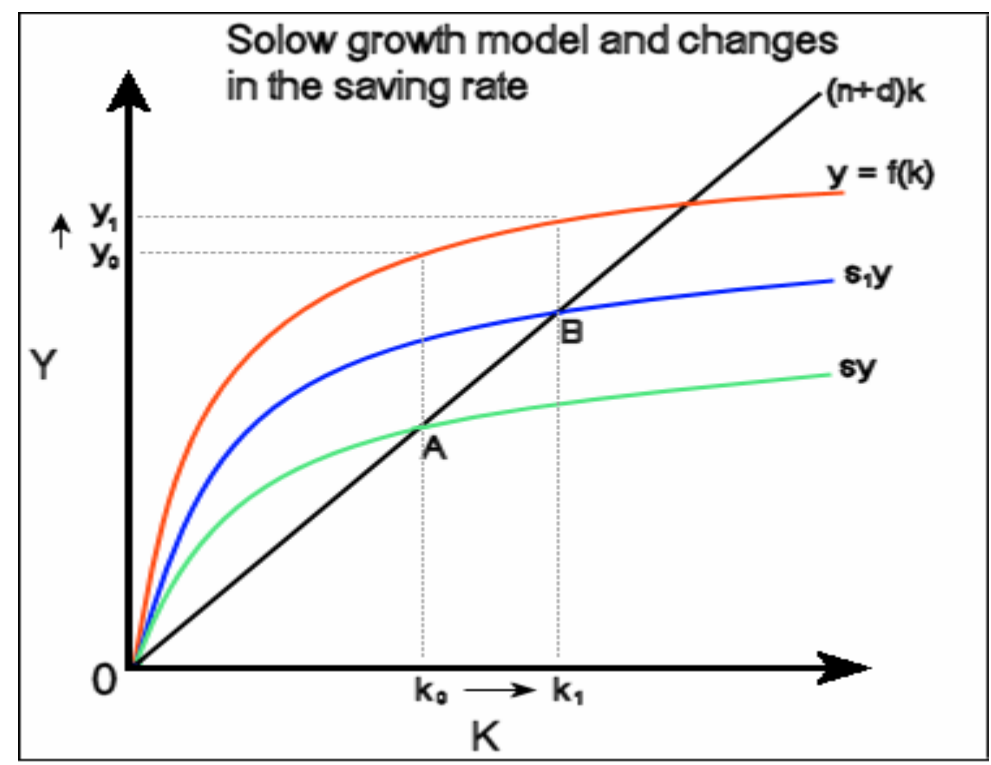

Gambar 2. Model Pertumbuhan Solow dengan Perubahan Pada Tingkat Tabungan

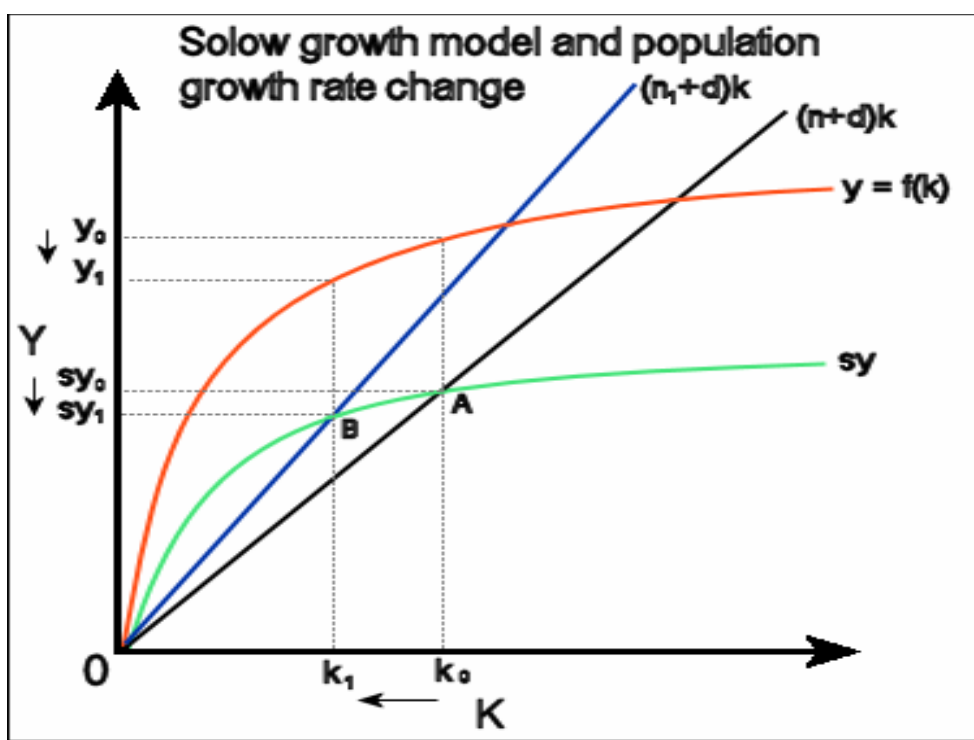

Grafik 3. Model Pertumbuhan Solow dengan Perubahan pada Pertumbuhan Penduduk

Pada model Solow dengan garis capital widening baru $(\mathrm{n} 1+\mathrm{d})$. pertumbuhan penduduk seperti Kondisi steady-state baru, yaitu titik B, digambarkan pada grafik di atas, memiliki tingkat modal per pekerja kenaikan tingkat pertumbuhan yang lebih rendah dibanding kondisi penduduk dari n ke n1 menghasilkan steady-state awal di titik A. Model 
Solow memprediksi bahwa perekonomian dengan tingkat pertumbuhan penduduk yang lebih tinggi akan memiliki tingkat modal per pekerja yang lebih rendah dan karenanya pendapatan yang lebih rendah pula (Mankiw, 2006).

\section{METODE PENELITIAN}

Penelitian ini menganalisis dan membahas pengaruh tabungan, investasi dan pertumbuhan jumlah penduduk, sebagai faktor penentu pertumbuhan dan standard of living yang dicerminkan oleh pendapatan/PDB per kapita dalam jangka panjang, seperti yang ditunjukkan dalam Model Pertumbuhan Solow-Swan, sementara pengaruh perkembangan teknologi tidak dibahas.

Untuk memahami permasalahan penelitian, dalam pembahasannya akan dicoba untuk melihat hubungan variabel-variabel penelitian dengan pendekatan kuantitatif. Data yang dipergunakan sebagai bahan analisis berupa data sekunder dengan jenis data time series yang bersumber dari Asian Development Bank dalam bentuk data tahunan dari tahun1990 s.d 2008.
Untuk melihat pengaruh dan bagaimana hubungan antar variabel, alat analisis yang digunakan adalah dengan pendekatan Analisis Regresi Berganda melalui metode Ordinary Least Square (OLS), dengan pertimbangan bahwa pendekatan ini sanggup untuk menjelaskan hubungan antar variabel yaitu variabel independen (jumlah penduduk, tabungan, dan investasi) terhadap variabel dependen (pendapatan/GDP per kapita). Proses pengolahan data menggunakan Program Eviews 4.0.

Aadapun spesifikasi model analisis Regresi Berganda yang digunakan dalam penelitian ini adalah sebagai berikut $: \mathrm{Y}=\alpha_{0}+\alpha_{1} \mathrm{JP}+\alpha_{2}$ GDS $+\alpha_{3}$ GDCF $+\mu$. Di mana :

$\mathrm{Y} \quad=$ Pendapatan perkapita

JP $\quad=$ Persantase pertumbuhan penduduk

GDS = Gross Domestic Saving/ tabungan

GDCF = Gross Domestic Capital Formation/ invevestasi

$$
\begin{array}{ll}
\alpha_{0} & =\text { Konstanta } \\
\alpha_{2}-\alpha_{3}= & \text { Koefesien regresi } \\
M & =\begin{array}{l}
\text { Variabel gangguan (error } \\
\end{array} \\
& \text { term) }
\end{array}
$$


PEMBAHASAN

Dari model yang dipilih, selanjutnya akan dilakukan pengujian asumsi klasik meliputi Uji Heteroskedastisitas dan Autokorelasi. Uji Heteroskedastisitas dengan memakai Uji White dan Uji Autokorelasi memakai Uji Durbin Watson. Uji ini digunakan untuk menguji apakah model regresi memenuhi asumsi-asumsi klasik yang disyaratkan dalam pemberlakuan metode Ordinary Least Squares (OLS). Beberapa jenis uji yang masing-masing untuk memenuhi asumsi utama yaitu sebagai berikut :

Bertujuan untuk menguji apakah dalam model regresi, nilai residiualnya mempunyai distribusi normal atau tidak. Salah satu cara untuk mendeteksinya adalah dengan membandingkan uji Jarque-Bera (JB) dengan membandingkan $\mathrm{X}^{2}$ tabel. Jika nilai uji Jarque-Bara melebihi nilai kritis $\mathrm{X}^{2}$ tabel, maka hipotesis bahwa residual berdistiribusi normal akan ditolak. Berdasarkan hasil analisis Eviews diperoleh hasil Nilai Probabilita sebesar $0,647921>5 \%$ menunjukkan bahwa data tersebut memenuhi asumsi normalitas (lampiran 2).
Dilakukan untuk menguji apakah pencarian dari variabel pengganggu adalah konstan sesuai asumsi klasik. Berdasarkan hasil analisis Eviews diperoleh hasil dengan Nilai Probabilita obs*R-squered sebesar $0,114884>5 \%$ menunjukkan tidak adanya gejala heteroskedastisitas (lampiran 2).

Digunakan untuk menguji apakah terjadi korelasi di antara residual dalam serangkaian observasi. Jika terjadi korelasi berarti tidak memenuhi asumsi klasik._Berdasarkan hasil analisis eviews diperoleh hasil dengan nilai probabilita obs*R-squered sebesar $0,333549>5 \%$ menunjukkan tidak adanya gejala Otokorelasi (lampiran 2).

Berdasarkan analisis dengan menggunakan eviews, setelah melakukan uji asumsi klasik dan diketahui bahwa model regresi yang di didisain atau dibangun tidak melanggar asumsi klasik langkah selanjutnya adalah melakukan analisis statistik dan analisisi ekonomi terhada hasil regresi tersebut (lampiran 3).

Hasil regresi selanjutnya akan diuji secara statistik meliputi uji signifikansi parsial, uji signifikansi secara bersama-sama dan uji koefisien determinasi $\left(\mathrm{R}^{2}\right)$. Dilakukan dengan cara membandingkan nilai T-tabel 
dengan T-statistik dengan derajat keyakinan ( $\alpha$ ). Jumlah penduduk signifikan secara statistik pada derajat keyakinan $\alpha=5 \%$ di mana T-Tabel > T-Statistik $\quad(1,740>-1,055075)$; Saving signifikan secara statistik pada derajat keyakinan $\alpha=5 \%$ di mana TTabel > T-Statistik $(1,740>0,905394)$; Investasi tidak signifikan secara statistik pada derajat keyakinan $\alpha=5 \%$ di mana T-Tabel > T-Statistik $(1,740<$ 5,498711); dan hipotesis yang digunakan adalah :Ho : $\beta_{0}=0, \beta_{1}=0, \beta_{2}$ $=0, \beta_{3}=0 . \mathrm{H}_{\mathrm{A}}: \beta_{0}>0, \beta_{1}>0, \beta_{2}>0$, $\beta_{3}>0$

Dari hasil di atas dapat disimpulkan bahwa variabel jumlah penduduk dan tabungan (GDS) secara parsial berpengaruh secara signifikan terhadap pendapatan perkapita nasional, artinya hipotesis nol (Ho) ditolak dan menerima hipotesa alternatif (Ha). Sementara itu untuk variabel investasi (GDCF), secara parsial tidak berpengaruh secara signifikan terhadap pendapatan perkapita nasional, artinya hipotesis nol (Ho) diterima dan menolak hipotesa alternatif (Ha).

Dilakukan dengan cara membandingkan F-statistik dengan derajat keyakinan $(\alpha)$. Dari hasil perhitungan besarnya probabilitas (F- statistik) $=136,1766$ dan derajat keyakinan ditetapkan sebesar $\alpha=5 \%=$ 0,05 , sehingga $\mathrm{p} \_$value atau probabilitas $($ F-statistik $)<=5 \%=0,05$, yang artinya bahwa variabel-variabel independen secara bersama-sama mampu menjelaskan pendapatan/PDB per kapita nasional.

Menunjukkan seberapa besar proporsi variasi variabel bebas mampu menjelaskan variasi variabel tak bebas. Hasil regresi menujukkan nilai $\mathrm{R}^{2}=$ 0,9714 artinya bahwa 97,14 \% variasi variabel tak bebas yaitu pendapatan/PDB per kapita mampu dijelaskan oleh variasi variabel bebasnya, sisanya dipengaruhi sebesar $2,86 \%$ oleh variasi variabel lain di luar variabel tersebut.

Setelah dilakukan analisis statistik dan ekonometrika, sesuai dengan tujuan penelitian maka dilakukan analisis secara ekonomi terhadap variabel bebas terutama jumlah penduduk, tabungan (GDS), dan investasi (GDCF) terhadap pertumbuhan pendapatan/PDB per kapita.

Koefisien variabel jumlah penduduk negatif $(-1578,236)$ dan signifikan terhadap pendapatan perkapita. Secara statistik jumlah penduduk mengalami peningkatan $1 \%$ 
maka akan diikuti dengan penurunan pendapatan/GDP per kapita nasional sebesar Rp 157.823,6. Artinya bahwa penambahan jumlah penduduk secara nasional dapat menurunkan pendapatan per kapita nasional. Hal ini disebabkan karena semakin bertambahnya jumlah penduduk akan menyebabkan semakin banyak "kue" dari pendapatan/PDB yang harus dibagi sebagai konsekuensi logis dari semakin bertambahnya jumlah penduduk. Hal relevan dengan hipotesis dalam Model Pertumbuhan Solow-Swan, bahwa pertumbuhan penduduk memiliki hubungan kebalikan/negatif dengan tingkat pendapatan per kapita.

Koefesien variabel tingkat tabungan (GDS) positif (0.004428) dan signifikan terhadap pendapatan per kapita. Secara statistik tingkat tabungan (GDS) mengalami peningkatan $1 \%$ maka akan diikuti dengan kenaikan pendapatan per kapita sebesar 0,44\%. Hal ini disebabkan karena semakin bertambahnya tingkat tabungan akan mempengaruhi besaran output yang pada akhirnya mempengaruhi pendapatan/PDB per kapita. Meskipun dalam persentase yang kecil, hal ini tentu saja relevan dengan hipotesis dalam model pertumbuhan Solow-
Swan, bahwa terdapat hubungan positiv antara tingkat pendapatan/PDB per kapita dengan tingkat tabungan (GDS).

Koefesien variabel tingkat investasi (GDCF) positif (0.013632) dan signifikan terhadap pendapatan per kapita (lampiran 3). Secara statistik tingkat investasi (GDCF) mengalami peningkatan $1 \%$ maka akan diikuti dengan kenaikan pendapatan per kapita sebesar 1,36 \%. Hal ini disebabkan karena semakin bertambahnya tingkat investasi akan mempengaruhi besaran output yang pada akhirnya mempengaruhi pendapatan per kapita. Sama halnya dengan tingkat tabungan (GDS), meskipun dalam persentase yang kecil, hal ini tentu saja relevan dengan hipotesis dalam model pertumbuhan Solow-Swan, bahwa terdapat hubungan positif antara tingkat pendapatan/PDB perkapita dengan tingkat investasi (GDCF).

\section{PENUTUP}

Berdasarkan hasil estimasi dan analisis yang telah dilakukan maka dapat disimpulkan beberapa hal sebagai berikut Secara teoretis, seperti digambarkan dalam model pertumbuhan Solow-Swan, standard of living yang dicerminkan oleh pendapatan per kapita 
suatu negara akan dipengaruhi oleh pertumbuhan penduduk, tingkat tabungan dan investasi. Mengacu pada model Solow-Swan, jika suatu negara menyisihkan sebagian besar pendapatannya ke tabungan dan investasi, maka negara itu akan memiliki persediaan modal pada kondisi steady-state dan tingkat pendapatan yang tinggi, dan sebaliknya. Sebaliknya, model Solow-Swan memprediksi bahwa negara dengan pertumbuhan populasi yang tinggi akan memiliki tingkat PDB per kapita yang rendah.

Hasil regresi menunjukkan bahwa selama periode 1990 - 2008 terdapat korelasi negatif antara pendapatan per kapita dengan pertumbuhan penduduk, atau dapat dikatakan pertumbuhan penduduk menyebabkan penurunan terhadap pendapatan per kapita penduduk Indonesia. Sementara itu, variabel tingkat tabungan (GDS) dan investasi (GDCF), meskipun dalam persentase yang kecil memberikan pengaruh positif terhadap pendapatan per kapita penduduk. Dapat disimpulkan bahwa sesuai dengan model Solow-Swan, pertumbuhan jumlah penduduk, tingkat tabungan, dan investasi berpengaruh terhadap
pendapatan/GDP per kapita penduduk Indonesia selama periode 1990 - 2008.

Dari kesimpulan yang telah diperoleh maka dapat dikemukakan beberapa saran sebagai berikut .Untuk meningkatkan pendapatan per kapita yang merupakan gambaran standard of living masyarakat, pemerintah perlu mengembangkan kebijakan ekonomi dan rencana pembangunan dengan kebijakan dan infrastruktur untuk memfasilitasi pertumbuhan ekonomi. Hal ini karena kecenderungan meningkatnya pendapatan/PDB per kapita akan menjadi dasar para perencana ekonomi untuk melaksanakan berbagai penyesuaian struktural untuk mencegah tingkat inflasi yang tinggi karena peningkatan daya beli anggota perorangan dari populasi.

Terkait dengan rendahnya kontribusi tingkat tabungan dan investasi terhadap pendapatan/PDB per kapita, pemerintah perlu mengeluarkan kebijakan investasi, dengan membuka peluang sebesar-besarnya baik penanaman modal asing (PMA) maupun penanaman modal dalam negeri (PMDN). 


\section{DAFTAR PUSTAKA}

Asian Development Bank, 2008. Indonesian Key Indicators. www.adb.org

FEUI, 2009. Indonesia Economic Outlook 2010. Jakarta : Penerbit PT Gramedia Widiasarana Indonesia

Madsen, Cathie. 2006. Pentingnya PDB Per Kapita. www.Nationmaster.com. (diakses pada tanggal 25 Nopember 2010)

Mankiw, N. Gregory (2006). Teori Makroekonomi Edisi Keenam. Terjemahan. Jakarta:
Penerbit Erlangga

Oktavia, Putu. (2005). Faktor-faktor yang Mempengaruhi Pendapatan Perkapita. Jurnal Ekonomi, http://www.96147.com// (diakses pada tanggal 16 Nopember 2010)

Poesoro, Awan Wibowo L. (2005). Membangkitkan Investasi di Indonesia.

www.theindonesianinstitute.com.

Tarigan, Robinson MRP. (2005). Ekonomi Regional (Teori dan Aplikasi). Jakarta : Penerbit PT Bumi Aksara 